\title{
INDEX TO VOL. VII
}

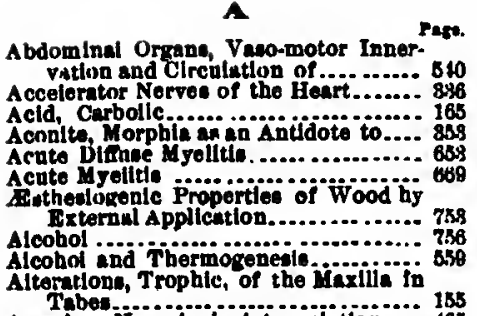
Tabes ..................... 155 Anestbesis of the Digestive Tracts in

Lrpemenla. ......................... BAb

Analyeule, Therapentic................ 844

Anutomy, Cerobrat ..................... 187 " Encephuilic .................... 80

" and Phyalology of the Nerr. ous s vatem...187, 898, B89, 789

Anlmols, Fimenre of Rolando it en Indes to the Infelligence of......... .

Anomalten, Cerehral................... 84

A phatien, daturni ne..... ................. 735

Apomurphle......................... 160

Apoplexy, 8tortoron, Breathlug In..... 748

Archltecture and Mechanlem of the

Brain .................... 98, ton

Arsenle Hypodermicaily in Chores ... 167

Anylum Manugarnent.................. 80

.1. Reform

Ataxic Artbropathles, Analyal of Bouen

In ............................... 840

Ataxy ................................ 848

Atropla........................... 858

"Action of npon the circuintion 168

" In Pertneafs.................... 165

Atrophy of the Cerebelium.............. 840

"1 Mecnier ..................... 60.

I8

Bacedor's Dicesue, Pathogeneals of ... 154 Bilateral qclerotis of the Cord after nui-

Interal Lesion of the Braln..........740

Blood-iotilng for Headuche ........... 854

Biood Vecesis, Action of Nituite of Amyl on ......................... 862

Bodily Wolght, Decreace in, ifter BpiIobtlo Attacke..................... 164

Books and Porlodicals Received....... 172. $858,568,761$

Braln Afreetions, Optic Fonitili In....

Brain, Arohtwetare and Mechnnlsm of-

Brain Dinease, Unilateral Convuluions dut to............................ 74

Brain, Gre and Wïhite Bubitance of ... so

" Microscoplan Studies of ........ 885

" Movemente of................. 78

Bromlde of Wthyl..............40,

Bromohydrate of Copils..................

Oafiein, Cltrate of

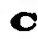

, Cltrate of ...................... 169

Genele, Semicl reniar ................... to.
Carhollc Acld ......................... Fo

Canse of Pnerperal Convulisioni........ ith

Cerebral Anomalien....................

"1 Anatnmy .................. if

" Complication of Chores..... It

"I Cortex, Vienal Aphere of ...... 11

"Disence, Afoction of viliö from..................... 747

-. Lncaliestion

Cerehro-8pinul Ganglie, Nervo Celi of. of Cerehro-Splnal Byetem, Plan of ........ Cerehrnm. Physiolong of the Normal sphere of ...........................

Cerebellum. Airophy of.................. Corlum. Oxinte of ..................... to Oervical Pechrmoningitia............... dito Chenges of Muscte Irritability dependont on Blood Bnppiy ............... 149 Children, Hyoterte In................... 76 " Insenity ln. ................... Ohlora $\ldots \ldots \ldots \ldots . . . . . . . . . . . . . . . .166,108$ " Ensecti of ....................... " Hydrate..... ................... Ib "1 Inebrlety .................... 19

Chloroform......................... I98

Chorea, Arsenic Hypotiermicali In.... if " Cerebral vomplicatione of..... 141 " Futul............................ 68 4 Peralitic.......................... 7to

Chorda Tympanl Nerve............... 889

Clachonidia ........................... 706 Circulation, Actiou of Atropia on....... 168 Coccutun Indicne in Epllopery.......... 7b4 Cotree and Tos ..................... The Colncidence of Optic Neuritie and inb. Acnte Traneverwe Myelitie......... 1w Colic. Hepa'ic........................ in Color, Pi reepilon of .................. Colored Lights, Raplaity of Perception of.................................... 968 Colnmne, Limiled soieropie of tho Z̈itoral and Ponterfor.................... Conditlon of the Pupli in General Pe

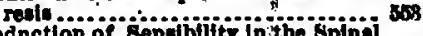
Condnction of Bentibilit; inithe spinal Cord ........... Condnction of Beneor rind Motor Im. pniven In the Cord.................. 146

Conla, Hromohydrate ..................... Conjurate Deviatlon of the Head ind Eyes ............................... 4 A8

Contractnres .......................... 108 Contrgetility, Biectro-muecniar........ 84 Contribntions to Nervous and Mentai Putbology ......................... 618 Coutrihntione to Paychitatry............ ब1 Convnisione, Puerperal, Ceuse of ...... 148 Convalsions, Unllateril dne to Brain Disease umne of .......................... Comes, Norves of ...................... 146 Corpor Quedrimemina.................. Crunlal Thermowetry ................... 70 Crimianllty ............................ Cutaneond rierves.................... 81

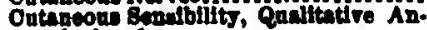
alyds of.......................... 


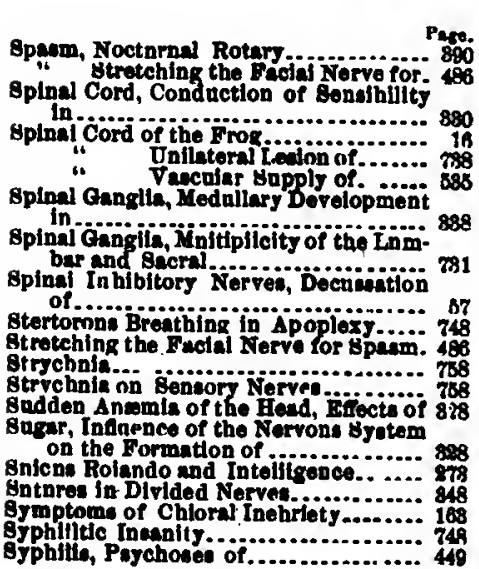

\section{$\mathbf{T}$}

Tabee, Norve Stretrhing in

75

Taben Dormalis, Etlology of............. 848

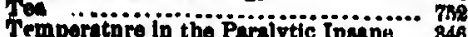
Tondon-Rofleres and Thelr Rolation to

Mnecular Tonne.................... moy

Tetenne................................ 189

Thafumio Epilepay........................ 492

Thafietrum Macrocarpnm.............. 168

Therapentice of the Nervone 8ystem

and Mind........... 165, 84, 600 , 750

Thermometry, Cranial................. 789 Tohacco

Topography of the Nerve Pibers in the

Trunt of the Optac Nerved.......... 887
Tortloollia, Flectriclty in Pare. Transfer-Phenomene in Epilopay Prodnced by Encircling Blloter....... 240 Treantory Paralyalo in Children Foifowed hy Permanent Deafness...... Ba

Trannfer of Beneations.... ........... 40 Truastre of Remplbilisy ............. 144, 880 Trestment of Epilepey Tremor. Qulveulc Bath in Treatment of 76 Trtyrminas, Vaso-Dilator Brects of $\mathrm{Rx}$ clation of

Tronhic Aiteratione of the Maxilia in Tabeu............................. 155

Tubereniar Mëingitia

Tumor of the Encephaion...............

\section{$\boldsymbol{U}$}

Unilateral Convaleione dne to Brain Dleeace......................... 74 Unliatent Lesion of the spinai coird.... 798

\section{$\nabla$}

Veen-Dilator - Rfferth of Excitation of the Perlpheral Find of the TrigemInqe.............................

Veso-Motop Innerration end cirenli: tton of the Llver and Abdominas Organe............................. 540 Vennus Clreniation of the Brain........ 781 Vision, Acrtenese of.................. 898 vielon. Aftections of from Corehrai Direnue......................... 747 Vinnof Bphere of the Cerobrai cortex... 14 vitilien. Changes in the Cntaneone Nerves in........................... 841

$\boldsymbol{W}$

Watar as a Propbriactic................ 484 Wood, Ainthewogenjo Properties of..... 769 